\title{
INFLUENCE OF THE ENVIRONMENT ON THE OPERATIONAL SAFETY OF A FLUIDIZED BED BOILER
}

\author{
doi: $\quad 10.2478 /$ czoto-2019-0086
}

Date of submission of the article to the Editor: $27 / 11 / 2018$

Date of acceptance of the article by the Editor: 14/01/2019

\author{
Agata Dudek ${ }^{1}$-orcid id: 0000-0001-9115-028X \\ Rafał Kobyłecki ${ }^{2}$-orcid id: 0000-0002-5367-408X \\ ${ }^{1}$ Częstochowa University of Technology, Poland, dudek.agata@wip.pcz.pl \\ ${ }^{2}$ Częstochowa University of Technology, Poland
}

\begin{abstract}
The use of fluidized bed boilers in modern power engineering is a promising solution for clean and economically acceptable combustion of various fuels, including coal, biomass and waste, for the generation of electricity. The fluidized bed boilers are nowadays technically advanced and complex combustion facilities where all individual boiler elements are subjected to withstand continuous structural and thermal loads during their operation. Intensive loading of boiler elements can be quite easily linked with boiler operational safety and is quite often one of the main reasons for emergency shutdowns followed by necessary replacements of the damaged items. In case of industrial large-scale circulating fluidized bed boilers the frequency of unplanned shutdowns is also quite often affected by the hydrodynamics of the fluidized bed and some other parameters, such as the intensity of solids circulation, temperature, solids concentration, flue gas composition and velocity, solids accumulation and deposition, as well as the corrosion or erosion of heat transfer surfaces. The present paper briefly reports the results of authors investigation focused on the morphology and structure of some chosen elements (steel anchors) sampled from one of Polish circulating fluidized bed boilers. The anchors were degraded during boiler operation and lost their mechanical durability. In order to determine the reasons of anchors' degradation chemical composition of the elements was determined with the use of a spark spectrometer SPECTROLAB and sample morphology was investigated with JEOL JSM-6610LV scanning microscope equipped with LaB6 cathode.
\end{abstract}

Keywords: fluidized bed boiler, anchors, refractory damage

\section{INTRODUCTION}

Continuous increase in the consumption of power, lack of fossil fuel resources at reasonable prices and real perspectives to counteract climate changes require the development of advanced and environmentally-friendly energy conversion technologies (Yu et al., 2003; Demirbas et al., 2009; Ud Din and Zainal, 2016). Recently, more and more attention is put to the fluidized bed combustion technology 
(Leckner et al., 2011; Shrestha et al., 2016) mainly due to its numerous advantages, such as the ability to cofire various fuels, low emission of NOx and high combustion efficiency. Nowadays, many various types of fluidized bed boilers are under operation, such as:

- Bubbling fluidized bed boilers with atmospheric pressure, A-BFB or BFB,

- Pressurized bubbling fluidized bed boilers, PBFB,

- Circulating fluidized bed boilers with atmospheric pressure, A-CFB or CFB, and pressurized circulating fluidized bed boilers, PCFB.

The majority of currently-operated fluidized bed boilers in Poland are A-CFB type units and they have been under commercial operation since over 25 years. The circulating loop of a circulating fluidized bed (CFB) boiler consist of a combustion chamber, one or more (up to 8) cyclones and solids recirculation system consisting of a downcomer, a loopseal and return legs. The flue gas with fine fly ash that is not separated by the cyclone pass through the 'so called' second section where convective heat exchangers (steam superheaters, economizer and air preheater) are located. The combustion process takes place in the furnace where the temperature is maintained at approximately $850-860^{\circ} \mathrm{C}$ to control the emission of sulfur and nitrogen oxides and to avoid any solids agglomeration and bed defluidization. The live steam superheaters are located either in the combustion chamber or in the convective pass. The temperature of the live steam in the superheaters is controlled by interstage injection coolers.

Modern power generating facilities are technically complicated objects. Almost all individual elements of the facility are subjected to continuous and/or variable structural and thermal loadings (Osocha et al., 2004; Weglowski and Osocha, 2009). Furthermore, many of them also have to withstand very harsh conditions and maintain sufficient mechanical durability at high temperature (Guidoni et al., 2005; Mazur et al., 2018; Osocha, 2018) and pressure and be erosion- and corrosion-resistant (Wlodarczyk and Dudek, 2011; Szabracki and Lipinski, 2014a; Szabracki and Lipinski, 2014b). The requirements for the durability of boiler elements are becoming more strict in case the coal is co-combusted with high alkali and/or chlorine containing fuel, such as biomass or waste (e.g. the refuse-derived fuel, RDF) since in the furnaces of such boilers the degradation of refractory or steel elements (Mazur and Mikova, 2016) is accelerated and the damage elements have to be replaced more frequently. Unfortunately, quite often the damages occur during boiler 'ordinary' operation thus leading to uncontrolled emergency shutdowns and increased boiler operational costs. The risk of failure has to be predicted, controlled and finally lowered using a variety of possible methods (Nowakowska-Grunt and Mazur, 2015; Nowakowska-Grunt and Mazur, 2016; Pietraszek et al., 2017; Kozien and Kozien, 2017; Maszke et al., 2018). In order to minimize those costs and improve the durability of boiler elements modern material engineering proposes advanced solution and application of e.g. ceramic linings, corrosion and erosion resistant alloys (Szczotok and Rodak, 2012; Szczotok and Chmiela, 2014; Scendo et al., 2014; Domagala et al., 2018b), ceramic coating spraying (Pobedza and Sobczyk, 2013) or other special composite materials (Korzekwa et al., 2018; Radek and Bartkowiak, 2011; Pliszka et al., 2018; Radek et al., 2018a; Radek et al., 2018b). Those ceramic materials can be used in corrosive environments and are temperature resistant up to $1200^{\circ} \mathrm{C}$ and are particularly suited to protect lower parts of the membrane walls in the boiler furnace and the wall area at 
cyclone inlet and inside of the cyclone where high solids concentration and high gas velocity bring about intensive attrition. The working parts of the ceramic refractories are coupled to boiler steel structure and furnace membrane walls by anchors which are made of stainless steel and their main task is to provide high mechanical durability of the composite element, while the ceramic refractory is responsible for high protection against erosion and corrosion.

\section{METHODOLOGY OF RESEARCH AND RESULTS}

The investigated anchor and refractory samples were obtained from one of Polish large scale CFB boilers burning coal and coal slurry with some minor $(<10 \%)$ addition of the agromass (sunflower or wood pellets). An exmple view of the refractory and the anchors is shown in Fig. 1. The refractory was damaged since all anchors lost their mechanical properties and came off the membrane wall.

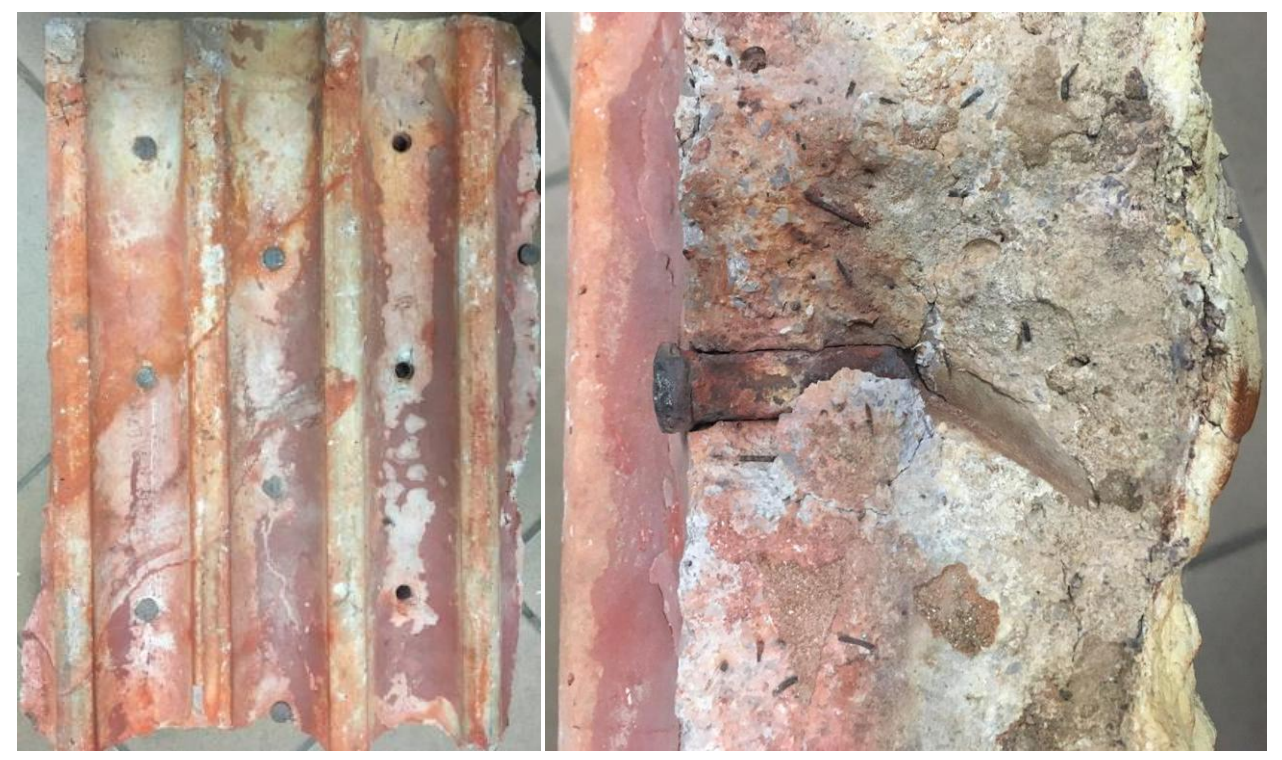

Fig. 1. Damaged ceramic refractory with visible anchors

In order to analyze the reasons for the cracking and damage of the anchors, macroscopic investigations and analysis of the chemical composition and structure of the anchors was carried out with the use of the SPECTROLAB spark spectrometer and JEOL JSM-6610LV scanning microscope with the LaB6 cathode. The macroscopic view of the anchors is shown in Fig. 2 while chemical composition of the anchors is summarized in Table 1 . The values in Table 1 sum up to $100 \%$ - the remaining element is iron $(\mathrm{Fe})$.

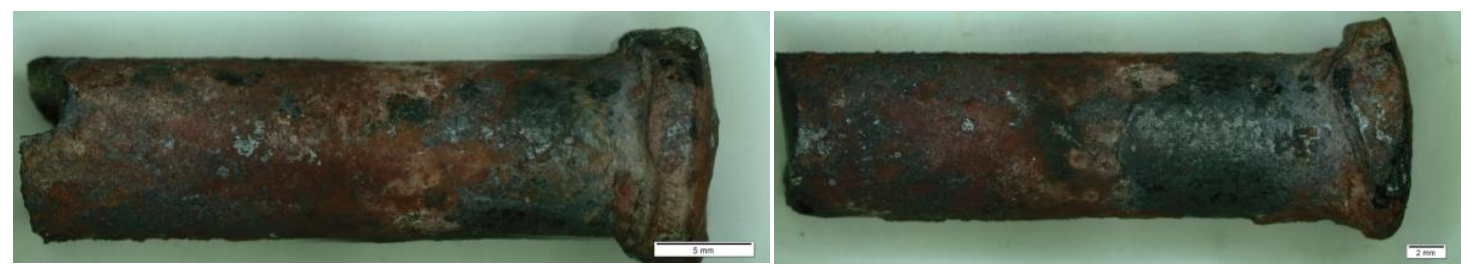

Fig.2. Macroscopic view of the investigated anchor samples 
Table.1.

Chemical composition of the anchors (the values are in wt\%)

\begin{tabular}{|l|l|l|l|l|l|l|l|l|l|l|l|}
\hline $\mathbf{C}$ & $\mathbf{S i}$ & $\mathbf{M n}$ & $\mathbf{P}$ & $\mathbf{S}$ & $\mathbf{C r}$ & $\mathbf{M o}$ & $\mathbf{N i}$ & $\mathbf{A l}$ & $\mathbf{C o}$ & $\mathbf{C u}$ & $\mathbf{N b}$ \\
\hline 0.029 & 2.56 & 1.46 & 0.038 & 0.005 & 24.10 & 0.26 & 20.31 & 0.01 & 0.11 & 0.30 & 0.023 \\
\hline
\end{tabular}

Analysis of the chemical composition of the samples indicated that the steel anchors are made of heat-resistant stainless steel AISI $310 \times 15 \mathrm{CrNiSi25-20.} \mathrm{The} \mathrm{steel} \mathrm{has} \mathrm{an}$ austenitic structure and is designed to work in particularly high temperatures according to PN-71 / H-86022, EN 10095. The steel belongs to the group of steels that combine high temperature properties with good plasticity and weldability and are resistant to oxidation under constant temperature conditions up to $1150^{\circ} \mathrm{C}$.

The cross-section view of the investigated anchor is shown in Fig. 3. Analysis of the breakthrough revealed brittle cracking and increased number of sigma precipitates in the damaged anchors. Those sigma precipitates contributed directly to the formation of cracks and damage of the anchors since the sigma phase is an intermetallic phase that is hard and chromium-rich and its presence in the steel structure causes significant drop of the resistance of the steel against impacts or mechanical loadings.

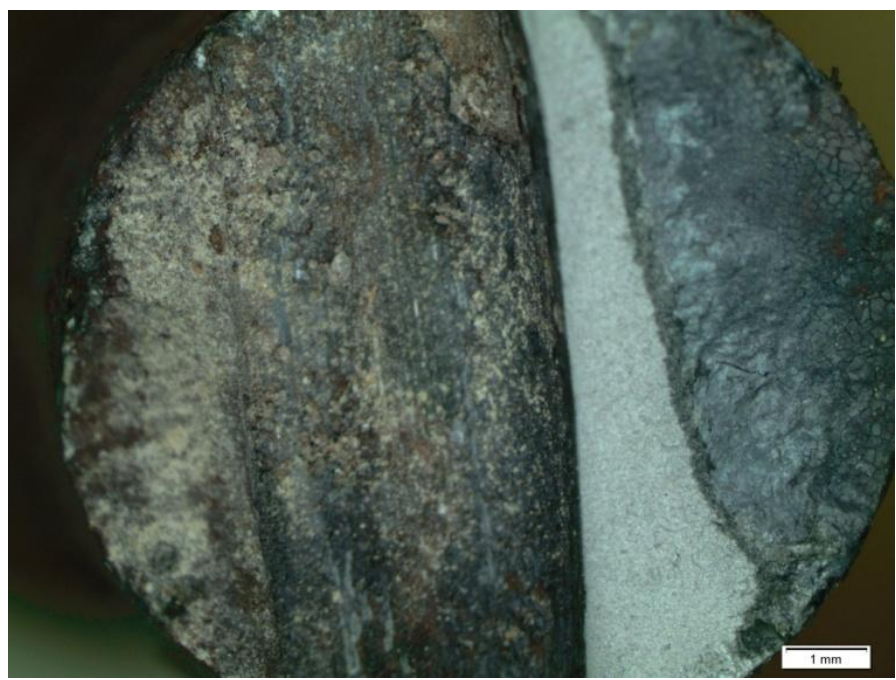

Fig.3. The cross-section view of the damaged anchor.

\section{CONCLUSION}

The safe operation of a large-scale CFB boiler is closely related to the strength and durability of the individual elements and the materials the boiler is made of, particularly that major part of the elements and materials work in extreme conditions (high temperature, mechanical stress, increased corrosion and erosion). Detailed knowledge of the operating conditions and limitations for individual materials and proper material design and manufacturing technology is thus the key to long-term and trouble-free operation of the boiler.

In the case of the investigated anchor samples (X15CrNiSi25-20) the formation of a large number of hard and chromium-rich intrusions was determined. Those intrusions were responsible for significant drop of anchor mechanical properties and damage of the elements. Accordingly, long-term operation of that type of steel in the temperature ranges between 500 and $900{ }^{\circ} \mathrm{C}$ is not recommended due to the risk of increased brittleness of the material brought about by the release of hard and brittle intermetallic sigma phase. 


\section{REFERENCES}

Demirbas, M.F., Balat, M., Balat, H., 2009. Potential contribution of biomass to the sustainable energy development. Energy Conv. Manag., 50(7), 1746-1760. DOI: 10.1016/j.enconman.2009.03.013

Domagala, M., Momeni, H., Domagala-Fabis, J., Filo, G., Krawczyk, M., 2018b, Simulation of Particle Erosion in a Hydraulic Valve. Mater. Res. Proc. 5, 17-24. DOI: $10.21741 / 9781945291814-4$

Guidoni, G., Dudek, A., Patsias, S., Anglada, M., 2005. Fracture behaviour of thermal barrier coatings after high temperature exposure in air. Mat. Sci. Eng. A-Struct., 397, 209-214.

Korzekwa, J., Gadek-Moszczak, A., Zubko, M., 2018. Influence of the Size of Nanoparticles on the Microstructure of Oxide Coatings. Mater. Sci. 53, 709-716. DOI: $10.1007 / \mathrm{s} 11003-018-0127-\mathrm{x}$

Kozien, E., Kozien, M.S., 2017. Interval analysis as a method of measurement of uncertainity in the check-list method applied to identification of stage phase of companies. $26^{\text {th }}$ Int. Sci. Conf. Economic and Social Development - Building Resilient Society: Economic and Social Development. Varazdin Development \& Entrepreneurship Agency, Varazdin, Croatia, 210-215.

Leckner, B., Szentannai, P., Winter, F., 2011. Scale-up of fluidized-bed combustiona review. Fuel, 90(10), 2951-2964. DOI: 10.1016/j.fuel.2011.04.038

Maszke, A., Dwornicka, R., Ulewicz, R., 2018, Problems in the implementation of the lean concept at a steel works - Case study. MATEC Web Conf., 183, art. 01014. DOI: 10.1051/matecconf/201818301014

Mazur, M., Kucharikova, L., Tillova, E., Chalupova, M., 2018. A change of mechanical properties of the self-hardening UNIFONT 90 due to temperature. Mater. Res. Proc., 5, 136-141. DOI: 10.21741/9781945291814-24

Mazur, M., Mikova, K., 2016. Impact resistance of high strength steels. Mater. TodayProc. 3, 1060-1063. DOI: 10.1016/j.matpr.2016.03.048

Nowakowska-Grunt, J., Mazur, M., 2015. Safety management in logistic processes of the metallurgical industry. METAL 2015: $24^{\text {th }}$ Int. Conf. Metallurgy And Materials, Ostrava, Tanger, 2020-2025.

Nowakowska-Grunt, J., Mazur, M., 2016. Effectiveness of logistics processes of SMES in the metal industry. METAL 2016: $25^{\text {th }}$ Int. Conf. Metallurgy And Materials, Ostrava, Tanger, 1956-1961.

Osocha, P., Duda, P., Weglowski, B., 2004. Determining temperature and stress changes in thick-walled elements of steam lines. Inz. Chem. Procesowa 25, 22492256.

Osocha, P., 2018. Calculation of Residual Life for P91 Material Based on Creep Rate and Time to Rupture. Mater. Res. Proc. 5, 177-182. DOI: 10.21741/9781945291814-31

Pietraszek, J., Dwornicka, R., Krawczyk, M., Kołomycki, M., 2017. The nonparametric approach to the quantification of the uncertainty in the design of experiments modelling. UNCECOMP 2017, NTU of Athens, 598-604. DOI: 10.7712/120217.5395.17225

Pliszka, I., Radek, N., Gadek-Moszczak, A., Fabian, P., Paraska, O., 2018. Surface improvement by WC-Cu electro-spark coatings with laser modification. Mater. Res. Proc. 5, 237-242. DOI: 10.21741/9781945291814-42 
Pobedza, J., Sobczyk, A., 2013. Modern Coating Used in High Pressure Water Hydraulic Components. Key Engineering Materials, 542, 143-155. DOI: 10.4028/www.scientific.net/KEM.542.143

Radek, N., Bartkowiak, K., 2011. Laser Treatment of Cu-Mo Electro-Spark Deposited Coatings. Physcs. Proc., 12, 499-505. DOI: 10.1016/j.phpro.2011.03.061

Radek, N., Szczotok, A., Gadek-Moszczak, A., Dwornicka, R., Broncek, J., Pietraszek, J., 2018a. The impact of laser processing parameters on the properties of electro-spark deposited coatings. Arch. Metall. Mater., 63, 809-816. DOI: $10.24425 / 122407$

Radek, N., Pietraszek, J., Szczotok, A., 2018b. Microstructure and tribological properties of esd coatings after laser processing. Mater. Res. Proc. 5, 206-209. DOI: 10.21741/9781945291814-36

Scendo, M., Trela, J., Radek, N., 2014. Influence of laser power on the corrosive resistance of $\mathrm{WC}-\mathrm{Cu}$ coating. Surf. Coat. Tech., 259, 401-407. DOI: 10.1016/j.surfcoat.2014.10.062

Shrestha, S., Ali, B.S., Binti Hamid, M.D., 2016. Cold flow model of dual fluidized bed: A review. Renew. Sust. Energ. Rev., 53, 1529-1548. DOI: 10.1016/j.rser.2015.09.034

Szabracki, P., Lipinski, T., 2014a. Influence of sigma phase precipitation on the intergranular corrosion resistance of X2CrNiMoN25-7-4 super duplex stainless steel. Metal 2014: $23^{\text {rd }}$ Int. Conf. Metallurgy and Materials. Tanger, Ostrava, 476481.

Szabracki, P., Lipinski, T., 2014b. Effect of Aging on the Microstructure and the Intergranular Corrosion Resistance of X2CrNiMoN25-7-4 Duplex Stainless Steel. Solid State Phenom., 203-204, 59-62. DOI: 10.4028/www.scientific.net/SSP.203-204.59

Szczotok, A., Rodak, K., 2012. Microstructural studies of carbides in MAR-M247 nickel-based superalloy. Conf. Technologies and Properties of Modern Utilised Materials, IOP, vol. 35, art. 012006. DOI: 10.1088/1757-899X/35/1/012006

Szczotok, A., Chmiela, B., 2014. Effect of Heat Treatment on Chemical Segregation in CMSX-4 Nickel-Base Superalloy. J. Mater. Eng. Perform., 23, 2739-2747. DOI: 10.1007/s11665-013-0843-1

Weglowski, B., Osocha, P., 2009. Modelling of creep for $Y$ pipe from ferriticmartensitic P91 steel. Rynek Energii, 6, 140-145.

Wlodarczyk, R., Dudek, A., Nitkiewicz, Z., 2011. Corrosion analysis of sintered material used for low-temperature fuel cell plates. Arch. Metall. Mater. 56, 181-186. DOI: $10.2478 / v 10172-011-0021-0$

Ud Din, Z., Zainal, Z.A., 2016. Biomass integrated gasification-SOFC systems: Technology overview. Renew. Sust. Energ. Rev., 53, 1356-1376. DOI: 10.1016/j.rser.2015.09.013

Yu, L.-J., Cao, G.-Y., Zhu, X.-J., Jiang, A.-Z., Tian, Z.-P., 2003. Study on an environmental-friendly and high-efficient fuel cell energy conversion system. J. Environ. Sci., 15(1), 97-101. 